\title{
DEPOPULATION OF INTERSTITIAL CELLS OF CAJAL IN CHAGASIC MEGACOLON: TOWARDS TAILORED SURGERY?
}

\author{
Depleção de células intersticiais de Cajal no megacólon chagásico: a caminho do tratamento \\ cirúrgico individualizado?
}

\author{
Sergio Eduardo Alonso ARAUJO, Rodrigo Blanco DUMARCO, Viviane RAWET, \\ Victor Edmond SEID, Sylvio Figueiredo BOCCHINI, Sergio Carlos NAHAS
}

From the Discipline of Digestive Surgery and Coloproctology - Department of Gastroenterology - University of Sao Paulo, Sao Paulo, SP, Brazil.

HEADINGS - Megacolon. Chagas disease / surgery. Gastrointestinal diseases. Interstitial cells of Cajal. Constipation.

\section{Correspondência: \\ Sergio Eduardo Alonso Araujo \\ e-mail: sergioed@terra.com.br / sergioaraujo@colorretal.com.br}

Fonte de financiamento: não há Conflito de interesses: não há

Recebido para publicação: 04/11/2009 Aceito para publicação: 15/01/2010

DESCRTORES - Megacolo. Doença de Chagas. Gastroenteropatias. Células intersticiais de Cajal. Constipação intestinal.
ABSTRACT - Background - The mechanism of constipation in patients with Chagasic megacolon remains partially explained. In these patients, it was recently demonstrated a reduction in the population of interstitial cells of Cajal. Aim - To evaluate density of Cajal cells in the surgically resected colon of Chagasic patients in comparison to control patients, and to verify possible association between preoperative and postoperative bowel function of Chagasic patients and colonic cell count. Method - Sixteen patients with Chagasic megacolon were operated on. Clinical pre- and postoperative evaluation using the Cleveland Clinic Constipation Score was undertaken. Resected colons were examined. Cajal cells were identified by immunohistochemistry using anti-CD117 antibody. The mean cell number was compared to resected colons from 16 patients with non-obstructive sigmoid cancer. Association between preand post-operative constipation scores and cell count for megacolon patients was evaluated using the Pearson coefficient correlation test ( $r$ ). Results - A reduced number of Cajal cells [cells per field: $2.84(0-6.6)$ vs. 9.68 (4.3-13) - $p<0.001$ ] was observed in the resected colon of Chagasic patients when compared to colon cancer patients. No correlation between constipation score before $(r=-0.205 ; p=0.45)$ or after surgery $(r=0,291 ; p=0.28)$ and cell count for megacolon patients was observed. Conclusions Patients with Chagasic megacolon display marked reduction of interstitial cells of Cajal when compared to non-Chagasic patients. An association of constipation severity and Cajal cells depopulation in Chagasic megacolon could not be demonstrated.

RESUMO - Racional - A fisiopatologia da constipação intestinal nos pacientes portadores de megacólon chagásico permanece parcialmente esclarecida. Recentemente demontrou-se que nesses pacientes, o contingente de células intersticiais de Cajal está reduzido assim como ocorre em outros distúrbios funcionais gastrointestinais. Objetivo - Avaliar a densidade de células intersticiais de Cajal no intestino ressecado de pacientes submetidos a tratamento cirúrgico eletivo de megacólon chagásico em comparação com a observada no cólon de pacientes controles, e verificar possível associação entre o grau de constipação intestinal de pacientes com megacólon chagásico no pré e no pós-operatório e o grau de despopulação de células de Cajal. Método - Dezesseis pacientes com megacólon chagásico foram operados. A avaliação da função intestinal através do escore de constipação da Cleveland Clinic foi registrada antes e após a operação. O espécime cirúrgico foi examinado e as células de Cajal foram identificadas pela técnica imunoistoquímica empregando o anticorpo anti-CD117 (c-kit). O número médio de células de Cajal nos megacólons foi comparado com o de cólons ressecados de 16 pacientes [7 mulheres; média de idade de 62,8 (23-84)] operados de câncer não-obstrutivo do sigmóide. A associação entre o escore de constipação no pré e no pós-operatório e a contagem de células de Cajal foi medida através do coeficente de correlação de Pearson (r). Resultados - Redução significativa no número de células de Cajal (células por campo de 400X: 2,84 (0-6,6) vs. 9,68 (4,3-13) - ] foi observada nos megacólons quando comparados ao espécime de pacientes operados por câncer. Não foi observada associação entre o escore de constipação pré $(r=-0.205 ; p=0.45)$ ou pós-operatório $(r=0,291 ; p=0.28)$ a a contagem de células de Cajal para os pacientes com megacólon. Conclusões - Pacientes com megacólon chagásico exibem acentuada redução no número de células intersticiais de Cajal no intestino grosso. Não se pôde demonstrar associação entre grau de constipação e a intensidade da despopulação de células de Cajal no presente estudo. 
INTRODUCTION

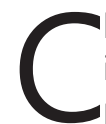

hagas disease or American trypanosomiasis is caused by Trypanosoma cruzi, an endemic parasite present in several regions of Latin America ${ }^{5}$. It is one of the most important endemic diseases in Brazil and South America, with more than 18 million individuals on the South American continent being infected and 120 million being at risk of acquiring the disease ${ }^{8}$.

Digestive involvement in Chagas disease involves the esophagus, leading to a megaesophagus with clinical and manometric features similar to that of idiopathic achalasia ${ }^{6}$ and the colon, causing megacolon. However, the entire bowel may be involved ${ }^{7}$. Megaesophagus is the most frequent digestive form of the disease. Megacolon is the second one and believed to be one third of the frequency of megaesophagus.

It is presently established that the involvement of the enteric nervous system is central in the pathogenesis of the gastrointestinal disorders in Chagas disease - the plexus theory ${ }^{22}$. Previous studies on colonic involvement have described degeneration and subsequent decreased number of intrinsic myenteric neurons ${ }^{1,18,24,25}$. The plexus theory hypothesis when denervation mainly affects the rectum might be confirmed by the high constipation recurrence rate when sigmoid resection and high colorectal anastomosis is attempted for surgical treatment ${ }^{3}$. Nevertheless, since almost all such data were obtained in Brazilian patients as single studies on a specific aspect, it might be true that this theory may not clarify important issues such as the discrepancy between congenital and Chagasic megacolon in terms of aganglionosis ${ }^{8}$. Moreover, the plexus theory does not explain, why dilatation is limited to the rectum and sigmoid colon even after 20-30 years of symptoms, and also the possible reason for the absence of rectal dilation in some cases ${ }^{17}$.

Recently, other cells have been found to play an important role in the regulation of gut motility and also in Chagasic megacolon. The interstitial cells of Cajal (ICC) are gastrointestinal tract cells ${ }^{28}$ working as pacemakers and acting as an intermediary in the spatial coordination of smooth muscle activity. These cells originate from the mesoderm, do not derive from the neural crest nor represent any special type of neuron or glial cell. In the colon, these cells can be found in the myenteric and in the circular and longitudinal muscle layers $^{8}$. The ability to visualize them derived from the fact that ICC express $\mathrm{C}-\mathrm{Kit}^{21}$. Immunohistochemistry techniques using c-Kit antibodies have provided some knowledge about ICC structure, networks and the interactions with intestinal smooth muscle and the enteric nervous system ${ }^{4}$. There is evidence from two studies regarding significant reduction in ICC density in Chagasic megacolons compared to non-Chagasic colons $^{8,11}$. Similar results have been reported by Wedel et al. ${ }^{30}$ for patients with constipation and megacolon of other etiologies. However, it remains unknown whether these findings are primary or secondary in the physiopathology of Chagasic megacolon ${ }^{8}$. In order to help clarifying this issue, we have hypothesized a possible correlation between constipation severity in patients with Chagasic megacolon and the degree of ICC density reduction.

In the present study, we aimed at observing if there was any correlation between ICC cell counting and preoperative and post-operative functional parameters represented by the Cleveland Clinic constipation score in patients with Chagasic megacolon undergoing elective surgical treatment. We also looked at ICC counting in Chagasic megacolon surgical specimens and non-Chagasic resected colon from cancer patients in order to reproduce the results of previous studies.

\section{METHOD}

The study protocol was approved by the Institutional Review Board at University of Sao Paulo Medical Center.

Sixteen patients with Chagasic megacolon, with indication for elective surgical treatment, were prospectively evaluated between 2006 and 2009 and represented the study group. All patients were from Brazilian regions where Chagas disease remains endemic. In all cases, the diagnosis of Chagasic megacolon was obtained from positive radiologic (megacolon at barium enema), serologic (positive indirect immunofluorescence or enzyme immunoassay), and functional (achalasia at anorectal manometry) test results. Clinical evaluation consisted of sex, age and result of the Cleveland Clinic Constipation score questionnaire ${ }^{2}$ before and close to 10 months after surgery. All 16 patients with Chagasic megacolon underwent a conventional or laparoscopic anterior resection with primary low end-to-side colorectal anastomosis at the posterior aspect of the extraperitoneal rectum as previously described ${ }^{23}$.

Sixteen patients with non-obstructive rectosigmoid adenocarcinoma operated on in 2007 represented the control group for ICC count, as there is evidence that ICC distribution is relatively uniform throughout the human colon ${ }^{20}$. All 16 control patients underwent an elective oncologic conventional or laparoscopic surgical treatment through anterior resection.

Cross section samples were obtained from the sigmoid of the surgical specimens for all 32 patients and processed for ICC identification and counting. Samples were fixed in buffered formalin for $48 \mathrm{~h}$, dehydrated in alcohol, and paraffin-embedded. Four $\mu \mathrm{m}$-thick sections were stained with hematoxylin-eosin. The slides used for immunohistochemistry were heated and incubated with hydrogen peroxide. The sections were then incubated with anti-CD 117 polyclonal antibody diluted $1: 500$ for $12 \mathrm{~h}$ at $4^{\circ} \mathrm{C} 20$. Staining of the cells 
was visualized by the streptavidin-biotin-peroxidase method. Kit immune-staining was carried out using a peroxidase-based visualization kit, following the manufacturer's recommendations. Kit-positive mast cells served as internal control. ICC were counted in 10 microscopic fields at a large magnification (400X) in the longitudinal and circular muscle layers and in the myenteric plexus.

The Wilcoxon and $\mathrm{t}$ Student tests were used to compare ICC counting between the two groups. Pearson correlation coefficient $(r)$ was used to determine correlation between pre-operative and post-operative constipation score and cell counting in the surgical specimen.

\section{RESULTS}

Twelve (75\%) patients in the study group and seven $(70 \%)$ in the control group (70\%) were female $(P=1.0)$. Mean age was $54.4(31-73)$ years in the study group and $62.8(23-84)-p=0.07$ in control patients.

ICC mean count was $2.84(0-6.6)$ cells per field in the study group and 9.68 (4.3-13) in the control group $(P<0.001)$ - Table 1.

TABLE 1 - Mean number of colonic intersticial Cajal cells in the surgical specimens of patients with Chagasic megacolon (study group) and sigmoid cancer (control)

\begin{tabular}{|c|c|cccc}
\hline Group & N & Mean & SD & Range & P \\
\hline Study & 16 & 2,84 & 2,00 & $(0-6.6)$ & $<0,001^{1}$ \\
\hline Control & 16 & 9,68 & 2,78 & $(4.3-13)$ & \\
\hline
\end{tabular}

Values are expressed as means. $\mathrm{N}=$ number of patients. $\mathrm{SD}=$ standard deviation. ${ }^{1}=$ Mann-Whitney non-parametric test descriptive value.

The mean Cleveland Clinic constipation score value for the study group was 21.6 (9-29) before and 3.4 $(0-16)$ after surgery. There was no correlation between constipation score value before $(r=-0.205 ; p=0.45)$ (Figure 1 ) or after surgery $(r=0,291 ; P=0.28)$ (Figure 2), and individual mean colonic ICC counting for the study group.

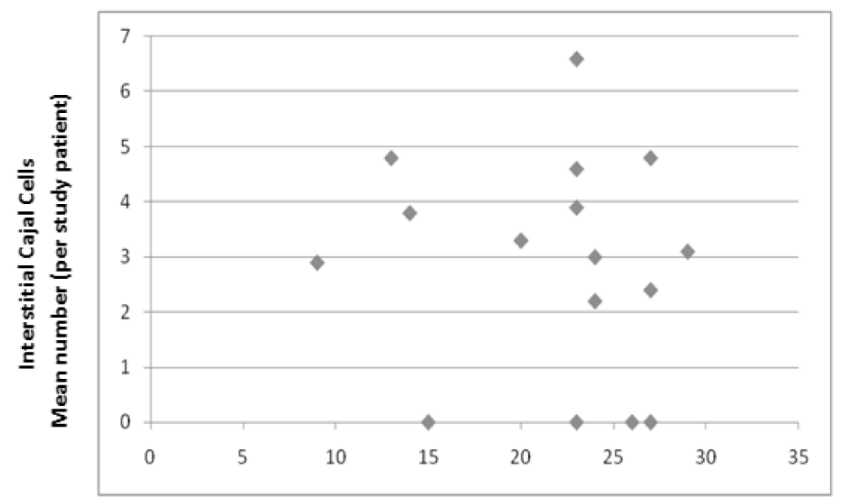

Cleveland Clinic Constipation Score Preoperative Value

FIGURE 1 - Correlation between preoperative Cleveland Clinic Constipation Score value and mean ICC count (study group). Mean preoperative score value $=21.6(r=$ $-0,205, p=0,447)$

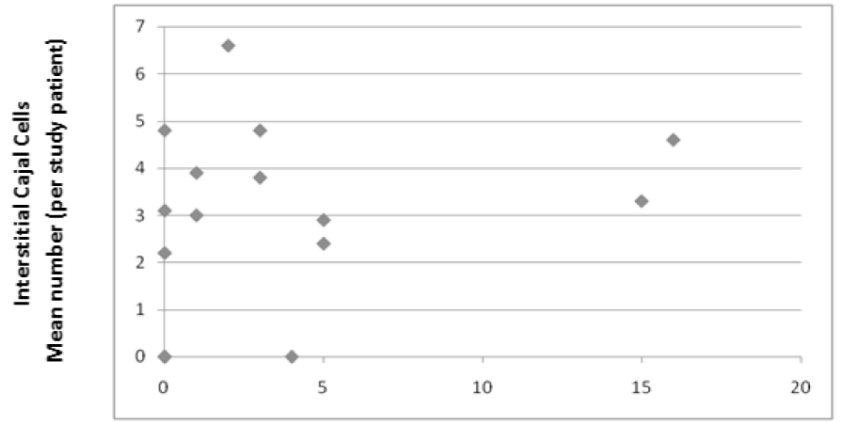

Cleveland Clinic Constipation Score Preoperative Value

FIGURE 2 - Cleveland Clinic Constipation Score postoperative Value. Correlation between postoperative Cleveland Clinic Constipation Score value and mean ICC count (study group). Mean postoperative score value $=3.4(r=0,291, p=0,275)$.

\section{DISCUSSION}

Surgery for Chagasic megacolon does not cure the disease. Main objectives are the relief of constipation and to reduce or nullify the risk of complications such as volvulus or fecal impaction ${ }^{3}$. Operations for Chagasic megacolon comprise a myriad of techniques that involve different extents of colon resection and anastomotic levels, resulting in variable operative morbidity and recurrence. Numerous surgical procedures have been used and, among these, the Duhamel technique has become the standard of care and received the most attention ${ }^{10}$. However, high morbidity rates and even some mortality are expected from modern application of this operation?.

In spite of the extensive experience of Brazilian and other south-American surgeons with the surgical management of Chagasic megacolon, the physiopathology of the disease remains not completely understood. The amount of basic and clinical research on the issue is near irrelevant. So far, there are only the report of Koberle ${ }^{9}$ and also from Okomura ${ }^{24,25}$, and Adad $^{1}$ suggesting that the histopathological basis of the digestive form of Chagas disease lies in the destruction of neuronal cells of the enteric nervous system And this so called plexus theory persists as the unrivaled physiopathologic guide for surgical treatment ${ }^{23}$.

The role of ICC in digestive motility disorders has been newly explored. A relative loss of ICC in colonic surgical specimens from children with congenital aganglionosis of Hirschsprung's disease was reported 29,31 . Decreased populations of ICC were observed in chronic idiopathic intestinal pseudoobstruction ${ }^{15,26}$, slow-transit constipation ${ }^{12,13,20,29,30}$, and also in diabetic gastroenteropathy ${ }^{13,16}$.

Hagger et al. ${ }^{11}$, Geraldino et al. ${ }^{8}$, and Iantorno et al. ${ }^{14}$ have demonstrated a reduction of ICC in the resected colon or in colonic biopsies in Chagasic patients with megacolon compared to the colon of non-Chagasic 
patients. Similar results have been reported by Wedel et al. ${ }^{30}$ for patients with constipation and megacolon of other etiologies.

In the present study, it was observed a marked reduction in the ICC counting in the colon resected from Chagasic patients when compared to colon cancer patients confirming the results of other authors ${ }^{8,11,14}$.

The next logical step would be to verify a possible association between the severity of constipation of patients with Chagasic megacolon and the degree of ICC depopulation in the large bowel of these patients. Moreover, if we could identify a correlation between ICC colonic depopulation and postoperative surgical results, this finding would be an initial step towards more tailored surgery for a strictly benign condition which still demands rectal mobilization and its associated morbidity. Unfortunately, in the present study, no correlation between preoperative or postoperative constipation scores and ICC counting was found.

This study has several limitations. First, the number of patients with Chagasic megacolon that could be analyzed and operated on represented a reduced sample. Second, although there was some difference in the group regarding the severity of constipation, it could not be observed any significant difference in the degree of colon dilation as determined by preoperative barium enema study. If this were the case, the study group could be stratified accordingly.

It is well known and confirmed in this study that important abnormalities of ICC in Chagasic megacolon exist. However, the reasons for ICC depopulation remain obscure. Further studies are needed in order to elucidate these issues and to verify a possible association between disease severity and the extent of reduction of ICC in Chagasic megacolon.

\section{CONCLUSIONS}

Patients with Chagasic megacolon display marked reduction of interstitial cells of Cajal when compared to non-Chagasic patients. An association of constipation severity and Cajal cells depopulation in Chagasic megacolon could not be demonstrated.

\section{REFERENCES}

1. Adad SJ, Cançado CG, Etchebehere RM, Teixeira VP, Gomes UA, Chapadeiro E, Lopes ER. Neuron count reevaluation in the myenteric plexus of chagasic megacolon after morphometric neuron analysis. Virchows Arch 2001;438(3):254-8.

2. Agachan F, Chen T, Pfeifer J, Reissman P, Wexner SD. A constipation scoring system to simplify evaluation and management of constipated patients. Dis Colon Rectum 1996;39(6):681-5.

3. Araujo SE, Dumarco RB, Bocchini SF, Nahas SC, Kiss DR, Cecconello I. Recurrence of chagasic megacolon after surgical treatment: clinical, radiological, and functional evaluation. Clinics (Sao Paulo) 2007;62(1):89-92.
4. Bettolli M, De Carli C, Jolin-Dahel K, Bailey K, Khan HF, Sweeney B, Krantis A, Staines WA, Rubin S. Colonic dysmotility in postsurgical patients with Hirschsprung's disease. Potential significance of abnormalities in the interstitial cells of Cajal and the enteric nervous system. J Pediatr Surg 2008;43(8):1433-8.

5. Chagas C. New Trypanosoma human infection. Morphologic and evolutive cycle of Schyzotrypanum cruzi. Mem Inst Oswaldo Cruz 1909:1:159.

6. Dantas RO, Aprile LR. Esophageal contractions in Chagas' disease and in idiopathic achalasia. J Clin Gastroenterol 2005;39(10):863-8.

7. de Oliveira RB, Troncon LE, Dantas RO, Menghelli UG. Gastrointestinal manifestations of Chagas' disease. Am J Gastroenterol 1998;93(6):884-9.

8. Geraldino RS, Ferreira AJ, Lima MA, Cabrine-Santos M, LagesSilva $E$, Ramirez LE. Interstitial cells of Cajal in patients with chagasic megacolon originating from a region of old endemicity. Pathophysiology 2006;13(2):71-4.

9. Habr-Gama A, Costa-Curta L, A. R. Surgical treatment for megacolon-Duhamel-Haddad technique. Rev Bras Cir 1982;9:25-31.

10. Haddad J. Treatment of acquired megacolon with rectro-rectal lowering of the colon of perineal colostomy (modified Duhamel operation). Rev Hosp Clin Fac Med S Paulo 1968;23:235-53.

11. Hagger R, Finlayson C, Kahn F, De Oliveira R, Chimelli L, Kumar D. A deficiency of interstitial cells of Cajal in Chagasic megacolon. J Auton Nerv Syst 2000;80(1-2):108-11.

12. He CL, Burgart $\mathrm{L}$, Wang $\mathrm{L}$, Pemberton J, Young-Fadok $\mathrm{T}$, Szurszewski J, Farrugia G. Decreased interstitial cell of cajal volume in patients with slow-transit constipation. Gastroenterology 2000;118(1):14-21.

13. He CL, Soffer EE, Ferris CD, Walsh RM, Szurszewski JH, Farrugia G. Loss of interstitial cells of cajal and inhibitory innervation in insulindependent diabetes. Gastroenterology 2001;121(2):427-34.

14. Iantorno G, Bassotti G, Kogan Z, Lumi CM, Cabanne AM, Fisogni S, Varrica LM, Bilder CR, Munoz JP, Liserre B, Morelli A, Villanacci V. The enteric nervous system in chagasic and idiopathic megacolon. Am J Surg Pathol 2007;31(3):460-8

15. Isozaki K, Hirota S, Miyagawa J, Taniguchi M, Shinomura $Y$, Matsuzawa Y. Deficiency of c-kit+ cells in patients with a myopathic form of chronic idiopathic intestinal pseudo-obstruction. Am J Gastroenterol 1997;92(2):332-4.

16. Iwasaki $H$, Kajimura $M$, Osawa $S$, Kanaoka $S$, Furuta $T$, Ikuma M, Hishida A. A deficiency of gastric interstitial cells of Cajal accompanied by decreased expression of neuronal nitric oxide synthase and substance $P$ in patients with type 2 diabetes mellitus. J Gastroenterol 2006;41(11):1076-87.

17. Kiss DR, Habr-Gama A, Pinotti HW. Megacólon chagásico: considerações sobre novas perspectivas fisiopatológicas. Rev Paul Med 1986;104:145-155.

18. Koberle F. Chagas' disease and Chagas' syndromes: the pathology of American trypanosomiasis. Adv Parasitol 1968;6:63-116.

19. Lee JI, Park H, Kamm MA, Talbot IC. Decreased density of interstitial cells of Cajal and neuronal cells in patients with slowtransit constipation and acquired megacolon. J Gastroenterol Hepatol 2005;20(8):1292-8.

20. Lyford GL, He CL, Soffer E, Hull TL, Strong SA, Senagore AJ, Burgart LJ, Young-Fadok T, Szurszewski JH, Farrugia G. Pan-colonic decrease in interstitial cells of Cajal in patients with slow transit constipation. Gut 2002;51(4):496-501.

21. Maeda H, Yamagata A, Nishikawa S, Yoshinaga K, Kobayashi $\mathrm{S}$, Nishi K. Requirement of c-kit for development of intestinal pacemaker system. Development 1992;116(2):369-75.

22. Meneghelli UG. Chagas' disease: a model of denervation in the study of digestive tract motility. Braz J Med Biol Res 1985;18(3):255-64.

23. Nahas SC, Habr-Gama A, Nahas CS, Araujo SE, Marques CF, Sobrado CW, Bocchini SF, Kiss DR. Surgical treatment of Chagasic megacolon by abdominal rectosigmoidectomy with immediate posterior end-to-side stapling (Habr-Gama technique). Dis Colon Rectum 2006;49(9):1371-8. 
24. Okomura M, Britto T, Silva LHP, Silva AC, Netto AC. The pathology of experimental Chagas' disease in mice: I. Digestive tract changes, with a reference to necrotizing arteritis. Rev Inst Med Trop S Paulo 1960;2:17-28.

25. Okomura MC. Contribution to the study of myenteric plexus neuron lesions of the colon in experimental Chagas' disease in albino mice (Mus musculus). Rev. Hosp. Clin. Fac. Med. S. Paulo 1967;22:192-204.

26. Streutker CJ, Huizinga JD, Campbell F, Ho J, Riddell RH. Loss of CD117 (c-kit)- and CD34-positive ICC and associated CD34positive fibroblasts defines a subpopulation of chronic intestinal pseudo-obstruction. Am J Surg Pathol 2003;27(2):228-35.

27. Tajana A, Manzullo V, Micheletto G, Orio A, Pellicani F, Pugliese G. Surgery for severe idiopathic constipation: a report of personal experience. ABCD Arq Bras Cir Dig. 1990;5(4):79-81.
28. Thuneberg L. Interstitial cells of Cajal: intestinal pacemaker cells? Adv Anat Embryol Cell Biol 1982;71:1-130.

29. Vanderwinden JM, Rumessen JJ, Liu H, Descamps D, De Laet $\mathrm{MH}_{\text {, }}$ Vanderhaeghen JJ. Interstitial cells of Cajal in human colon and in Hirschsprung's disease. Gastroenterology 1996;111(4):901-10.

30. Wedel T, Spiegler J, Soellner S, Roblick UJ, Schiedeck TH, Bruch $\mathrm{HP}$, Krammer HJ.. Enteric nerves and interstitial cells of Cajal are altered in patients with slow-transit constipation and megacolon. Gastroenterology 2002;123(5):1459-67.

31. Yamataka A, Kato Y, Tibboel D, Murata Y, Sueyoshi N, Fujimoto T, Nishiye $H$, Miyano T. A lack of intestinal pacemaker (c-kit) in aganglionic bowel of patients with Hirschsprung's disease. J Pediatr Surg 1995;30(3):441-4. 